\title{
Facilitating User Involvement in Activation Programmes: When Carers and Clerks Meet Pawns and Queens
}

\author{
ANNE BRITT DJUVE* and HANNE C. KAVLI** \\ *Fafo Institute for Labour and Social Research, Oslo, Norway \\ email: Anne.Britt.Djuve@fafo.no \\ ** Fafo Institute for Labour and Social Research, Oslo, Norway \\ email: Hanne.Kavli@fafo.no
}

\begin{abstract}
User involvement has become an explicit goal within social service provision. Even so, the term remains ambiguous, and its implementation troublesome. Implementation theory lists a number of factors influencing bureaucratic behaviour; in this paper we investigate the 'human factor'. Our ambition is to provide a framework for analysis of user influence in activation programmes that includes the individual characteristics of both service users and service providers. Building on theoretical insights from the literature on activation and agency, we develop a framework that distinguishes between two ideal types of service users: Pawns and Queens, and two types of service providers: care-oriented Carers and rule-oriented Clerks. This framework is then applied to identify key challenges for the interaction between users and caseworkers in two challenging situations: when service users express little or no agency and when they express agency that is incompatible with the overall goals of the programme. We find that Carers show pronounced reluctance to overrule the choices made by service users even when they have conflicting views - and tend to postpone decisions when they interact with Pawns. Clerks tend to overrule the decisions of Queens when they have conflicting views, and to make decisions on behalf of Pawns. The analysis draws on data collected from 126 qualitative interviews with service providers and participants in the Norwegian Introductory Programme for immigrants and a survey of 320 caseworkers.
\end{abstract}

\section{Introduction}

User involvement and influence ${ }^{1}$ have become key elements in activation programmes, at least at the rhetorical level. The strong focus on designing services in cooperation with the user requires discretionary judgements by service providers. The welfare state's front line - here represented by the activation workers and their clients/users - is thereby turned into an important policy arena. Yet, the professional status of activation workers is indistinct (Sainsbury, 2008) and the literature is inconclusive on whether or not administration of activation measures is incompatible with professional (social) work (Van Berkel and Van der Aa, 2012). As we understand it, Lipsky's (1980) influential work on what he 
termed 'street-level bureaucrats' was based on the understanding that any public employee who translates public policy into individualised and discretionary decisions must be, to some extent, both administrator and professional. The mix between them will however differ according to both structural (Bloom et al., 2003; Jewell, 2007) and individual (Van Berkel, 2007; May and Winter, 2007) factors. The service users will on the other hand vary in their capacity and motivations to engage in discussions of the content and targets of the activation programme (Wright, 2012). Our ambition here is to study the consequences an administrative or a more social-work-oriented approach may have for the development of user involvement - also taking into account that service user characteristics matter. Our case study is the Norwegian Introductory Programme for refugees and immigrants (NIP), a compulsory, but remunerated, qualification programme with a high employee to participant ratio.

The introduction of the NIP represented a marked shift in Norwegian integration policy, away from unconditional social benefits and voluntary low-intensity language training, towards a compulsory full-day, year-round activation programme. As in other European countries, opponents of activation schemes voiced concerns that these schemes would undermine the social and cultural rights of immigrants (Djuve, 2011). Multiculturalism, understood as unconditional support of cultural rights, may however be difficult to combine with the high socio-political ambitions that characterise Nordic welfare states. Brochmann and Djuve (2013) argue that the Marshallian concept of social citizenship is a more adequate measure in evaluations of the legitimacy of NIP than multiculturalism alone, and that the risk of illegitimate cultural assimilation should be weighed up against gains in social citizenship. User influence has been argued to be a key element in distinguishing empowering programmes that develop social citizenship from intrusive programmes that diminish social citizenship (Djuve, 2010).

In this study of user influence, we are particularly interested in the responses of service providers in challenging situations when service users express little agency and situations when they express 'bad' agency (Wright, 2012); that is, preferences that are interpreted by service providers to be incompatible with policy goals or conditions. We suggest an analytical framework for the analysis that builds on insights from Julian Le Grand, Hartley Dean and Sharon Wright, and also on insights developed through our own fieldwork.

\section{Agency and actors in the activating state}

The activating state expects an engaged role for citizens, including marginalised citizens (Taylor-Gooby, 2005; Jensen and Pfau-Effinger, 2005). According to Arnstein (1969), citizen participation in decision making is essential for empowerment and democracy. The transition from passive recipient of services 
to active subject engaging with services is believed to be at the centre of user empowerment (Small, 2000). The active citizen is assumed to be self-responsible, and claimants of public transfers are expected to take an active role in the process of becoming self-reliant. This role entails more autonomy and choice than the traditionally passive client role: service users should be empowered and Queenlike, rather than passive and Pawn-like. The typical mode of practice within activation policy is individually tailored programmes aimed at enhancing users' employability (Minas, 2009) - an ideal which rests on user involvement and thus on service providers' ability to allow user autonomy as well as users' ability to make use of the autonomy they are granted. In other words, user involvement in the shaping of services not only presupposes agency on the part of the service users, but the ability and willingness of service providers to interact with this agency.

The interactive character of agency underscores the importance of taking into account characteristics of both service users and service providers in a study of user involvement. Le Grand (2003/06) discusses how policy makers' ideas about human agency and motivation shape public policy. According to Le Grand, perceptions of service users' agency are decisive for choice of policy measures. Are service users considered to be active, autonomous agents (Queens) or passive individuals (Pawns)? He defines agency as capacity to undertake action. Le Grand argues that allowing the service user freedom of choice between service providers is a way of granting autonomy to service users - to treat them as Queens. His examples are, however, chosen from the education and the health sector. In the case of activation and involuntary clients, choice between service providers may be tricky to implement (though not impossible, at least not in all cases), and activation may in itself be seen as a hindrance for both user involvement (Hasenfeld, 1999) and agency. On the other hand, activation measures may also be used for developmental (Marston et al., 2005) or empowerment (Djuve, 2011) reasons. In this context, successful user influence may be of particularly high importance for the ethical legitimacy of activation measures (Djuve, 2011). Also, other obstacles to agency such as lack of information, language problems and health issues may be more important for participants in activation programmes, in particular when they are newly arrived refugees.

Similarly, ideas about how service providers operate also shape public policy. Again, according to Le Grand, the important characteristic here is not so much their capacity to act, but their motivation for action: are they driven by care for others, or purely by self-interest? He categorises service providers either as selfish 'Knaves' or altruistic 'Knights'. The 'Knave' is defined as 'an individual whose principal concern is to further his or her self-interest' (Le Grand 2003/o6: 25) while the 'Knight' is motivated by the prospect of helping others, even if there is no personal gain in sight. 
Le Grand's concepts of Knights, Knaves, Pawns and Queens were originally outlined to illustrate how service providers and service users are constructed in British public debate on social policy. We believe his model is also a good starting point for an analysis of the challenges inherent in service providers' facilitation of user influence. However, Le Grand's model has been criticised for being too simplistic. Dean (2003a: 702) argues that agency is not only rooted in what Le Grand describes as 'the capacity to act', but also in the 'actors understanding of their actions'. Agency, in this respect, entails different degrees of reflexivity: both having an idea about what you want, and how to get it. Wright (2012: 313) stresses that agency is 'context-specific, negotiated and differentiated in relation to identities'. Individuals who hold a sizeable capacity to act in some circumstances may be disempowered Pawns in others, and decision-making is complex. Contrary to Le Grand's assumption that service user agency is primarily individual and motivated by economic outcomes (ibid.: 312), Duncan and Edwards (1999) illustrated how care responsibilities and understandings of motherhood can be key to mothers' rationalities concerning the balance between care and employment.

\section{Service users}

Le Grand arrives at a model of motivation and agency in public policy where altruistic Knights and selfish Knaves in the social services meet service users who are either autonomous Queens or passive Pawns. Supposedly, the activating state favours autonomous Queens. On the other hand, activation programmes often entail sanctions that are intended to affect the behaviour of the participants and thereby potentially reduce individual autonomy. Sometimes service users behave in ways that are considered to be out of line with the programme, or pursue objectives that are deemed to be unrealistic or inapt. In the words of Wright (2012: 320): 'no conceptualization of agency is complete without incorporating the issues of bad intentions, actions and consequences'. However, what is to be deemed wise and/or morally good is highly disputable, and service users and providers may disagree both on whether a certain intention is (morally) good, and on the adequate means to pursue it. 'Bad' agency may refer to preferences for measures that service providers consider to be out of reach, outcomes that are deemed to be incompatible with programme policy, but also to what service providers think of as (morally) bad behaviour. Examples of the latter could in this setting be undocumented absence from the programme or attempts to sabotage the training. The ambition to modify 'bad' agency and curb 'irresponsible' freedoms (Dean, 2007) is an inherent paternalistic trait of activation policy.

In other words, an understanding of agency merely as 'capacity to act' may be inadequate when analysing user characteristics decisive for interaction with service providers. Also, it becomes evident that it is the characteristics of users, as 


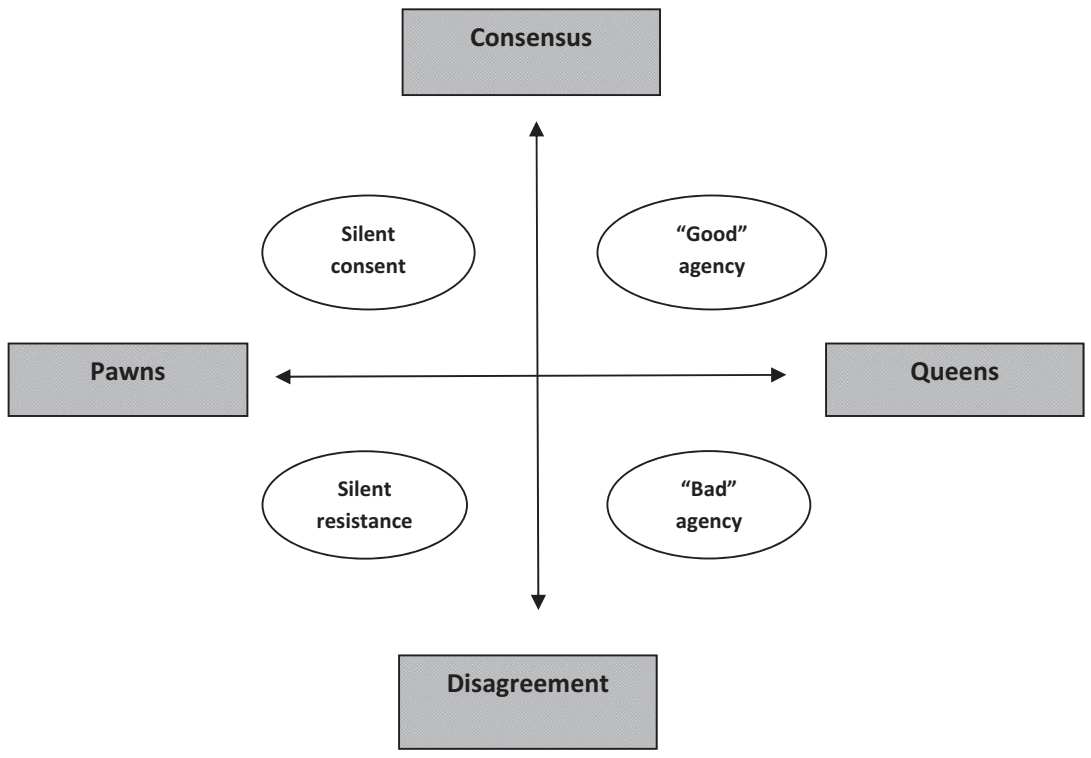

Figure 1. Service providers' perceptions of service user agency, by service user autonomy and level of consensus between service users and service providers

recognised and interpreted by service providers, that matters for user influence. The imbalance of power between users and providers of services is reflected in the fact that service providers not only tend to, but also get to, decide what is good and bad agency - and ultimately what is best for the participant. This process of categorisation depends on the level of consensus between users and providers: 'bad' agency is associated with a low level of consensus. On the other hand, both 'good' and 'bad' agency are also associated with some level of capacity to act, to communicate at least. Users who do not express their agency are difficult to place within the dimension of 'good' versus 'bad' agency. These users will typically be understood as silently consenting or silently resisting, though the difference may be hard to discern.

Figure 1 illustrates the four types of service user agency differentiated according to the level of consensus between the service user and the service provider, and the service users' capacity to act.

There is little doubt that 'good' agency is the most favourable condition for user involvement. On the 'Pawn' side of Figure 1, service providers struggle to make service users express their opinions. In the 'Bad' agency quadrant, the mission is rather to make them change their opinions. It is the encounters within these three problematic quadrants and the service providers' responses that will be at the centre of our empirical analysis: the silent either resistance or consent among Pawns, and the perceived bad agency among disagreeing Queens. 
TABLE 1. Care-oriented (Carers) and rule-oriented (Clerks) service provision

\begin{tabular}{ll}
\hline Care-oriented (Carers) & Rule-oriented (Clerks) \\
\hline - Flexible understanding of own tasks & • Clearly defined and rule-based \\
- Flexible and bargaining in user & understanding of own tasks \\
relations & - Strict and rule-bound in user relations \\
- Personal relation with the user & • Professional distance from the user \\
- Micro-oriented on results & - Macro-oriented on results \\
\hline
\end{tabular}

Source: Djuve and Kavli (2006: 214).

\section{Service providers}

As already stated, the interactive character of agency underscores the importance of taking into account characteristics of both service users and service providers in studies of user involvement. How individual decision makers' characteristics can affect their discretionary judgements has been a recurring topic in the literature on implementation (Loyens and Maesschalk, 2010). The consensus-disagreement dimension in Figure 1 illustrates that the chararacteristics of service providers are also important: the categorisation of user agency into 'good' and 'bad' is likely to depend on the service providers' knowledge, ingenuity and ideas. Though the Weberian ideal may be that service providers implement policy uniformly, a long tradition of empirical and theoretical work points to the importance of caseworkers' skills, attitudes and personal beliefs (Van Meter and Van Horn, 1975; Lipsky, 1980; Eriksen, 2001; Le Grand, 2003/o6; Dean, 2003a; Terum, 2003; May and Winter, 2007). These attributes are, however, difficult to observe and identify. It may also be argued that it is not the beliefs of service providers that affect user influence, but their actions. Le Grand's contribution divided service providers according to their motivations, either as self-interested Knaves or altruistic Knights. We define the service providers according to their actions and, in doing so, put more emphasis on professional practices than on motivations and morality.

In an earlier study of service providers in the Norwegian refugee service (Djuve and Kavli, 2006), we identified two types of bureaucrats with different responses to the challenges of local service provision (see Table 1). 'The main loyalty of the rule-oriented bureaucrat is to 'the system', and in many ways resembles Weber's ideal bureaucrat (Weber 1920/1978). Regulations are to be observed and officially outlined goals are to be adopted. The rule-oriented bureaucrat maintains a professional distance and relies on rules and regulations to guide them in interactions with users. Since their loyalty lies with 'the system', they are inclined to focus on overall goal achievement (as specified in policy documents) rather than individual results. On the other side of the continuum, we find the care-oriented bureaucrat. Their loyalty lies primarily with the service 
user. The care-oriented bureaucrat emphasises the diversity of cases, and thereby the need to adapt the services to each individual participant. They enter into long-term, personal relations with users and are inclined to put most effort into the most complex cases.

In the following we will refer to the two categories of service providers as 'Clerks' and 'Carers'. Both may have morally good intentions (of doing a good job) and they may be more or less reflexive in the way they relate to the bureaucratic framework and the service users.

In the empirical section, we will investigate the encounters between Carers and Clerks, Pawns and Queens, with a particular focus on the troublesome situations that service providers perceive as 'bad agency' or 'no agency' among service users. As bureaucratic behaviour is shaped by the environment in which it unfolds, we will first give a short description of the Norwegian context of immigration and integration.

\section{The Norwegian context of immigration and integration}

Service provider discretion is performed within national and local contexts. These contexts are shaped by rules, regulations and finances concerning social policy, but also by immigration policy, sentiments towards immigrants and the composition of new arrivals of immigrants (Jordan et al., 2003). Bureaucrats' strategies to facilitate user influence can also take on different forms depending on the programme at hand and the resources available (Jewell, 2007). Our case study is the Norwegian Introductory Programme (NIP) for refugees and immigrants. The main ambition for this two-year programme is that the participants achieve economic self-sufficiency. The economic sanctions are shaped in order to further participation of spouses as well as single parents.

The Norwegian immigration context is one of fairly recent immigration. Between 1980 and 2014, the immigrant population in Norway increased from 2.4 per cent to 12 per cent of the total population. ${ }^{2}$ In a comparative perspective, the Nordic welfare model is characterised by its high employment levels both among men and women, and by being service intensive. Immigrants, particularly of Asian and African origin, have employment levels well below those of the majority of the population. Among all refugees living in Norway in 2012, men had an employment rate of 54 per cent and women 45.6 per cent, compared to 71.6 and 65.7 per cent respectively for the total population of Norway (Olsen, 2014). The employment gap is particularly wide in the first years after arrival, but refugees continue to lag behind after several years.

The challenges of integrating migrants into the Norwegian labour market and society differ significantly according to the migrant's reasons for migration, formal skills and country of origin (Official Norwegian Report, 2011: 7). Participants in the NIP are refugees and many lack formal skills relevant to 
the Norwegian labour market. Many also come from societies characterised by traditional gender roles, something that in many cases adds to the problem (Djuve et al., 2011). When Norway introduced the NIP for newly arrived refugees and their families in $2004,{ }^{3}$ the aim was to give each participant basic skills in the Norwegian language, basic insight into Norwegian society and to prepare him or her for employment or education. The law was also clear in its gender egalitarian ambitions, emphasising that 'gender equality and the individual's responsibility for their own provision by means of paid employment has gradually become a central feature of Norwegian society', and that the programme should not be implemented in a way that would support any traditional gender roles (Proposition to the Odelsting nr.28, 2002-03: 68).

The Introductory act entitled newcomers to an individually tailored training plan as well as a modest fixed income (approximately $€_{21,000}$ EUR annually). This benefit is not means-tested, meaning that work on the side is possible without affecting payments. Every adult member of the household is entitled to the introductory benefit, as long as they participate full-time and according to their individual plan. This individual benefit had a double purpose: to reduce the risk of clientification by providing a direct link between active participation and payments and to promote full-time activation and, later on, employment among women. Parents with young children are offered subsidised childcare and special consideration is given to participants with health problems. The benefits are, however, conditional upon participation in a full-time (30-37.5 hours a week) qualification programme lasting up to two years (three years in special cases). Illegitimate absences from the set activities are deducted from the benefits, hour by hour.

By conditioning financial support on participation, extensive language and work training became compulsory for most newly arrived refugees and their families - an entire social category comprising highly diverse individuals. Every year, somewhere between 8,000 and 13,000 refugees are registered as participants in the NIP. ${ }^{4}$ There is no 'cherry picking' of candidates, as the programme is meant to be flexible enough to include everyone, regardless of education level, prior work experience or care responsibilities. As the content of the programme is not specified in much detail in the Introductory act, there is room for local adaptations. Adding to the 'staple' components of language training, social studies and work-oriented activities, municipalities have come up with an array of other courses. These additional courses are necessary in order to meet the requirements for full-time, individually adapted programmes and range from carpentry training and cooking classes to computer courses. There is also a wide range of other activities, such as helping children with homework, participating in psychiatric treatment or doing physical exercise (Kavli et al., 2007).

The Introductory Act (§6.3) (Ministry of Children, Equality and Social Inclusion, 2003) states that the programme should be based on an individual 
plan and that this plan is to be drafted 'in cooperation with the participant'. For successful cooperation, the participant needs to receive information so that he or she is able to make informed choices. The law and its regulations illustrate the expectation of both agency among programme participants and the service providers' facilitation of this agency. At the same time, the legal framework makes it clear that, if the participant disagrees with the municipality, the municipality has the last word. In other words, there is a limit to the influence users can have over their individual plan. The challenge for the service provider is to define and implement this limit.

\section{Data and methods}

The NIP was evaluated in 2007 and in 2011 and our data primarily stem from having undertaken these evaluations. ${ }^{5}$ The data comprise both quantitative and qualitative interviews, but the main emphasis in this article is on the qualitative data. All the individual interviews were semi-structured in order to make room for the respondents' own perspectives as well some key questions and topics.

\section{Individual interviews and focus groups with fifty-four NIP caseworkers and thirty-seven language teachers in the NIP programmes}

The researchers spent one or two days in each of the seventeen municipalities included in the qualitative part of the two studies. This enabled interviews to be combined with visits to the local training and counselling facilities. Focus groups (90-120 minutes) with three to four participants were conducted with both caseworkers and teachers. This gave the advantage of collegial reflection and added a dynamic to the discussions that the researchers as outsiders would otherwise have had difficulty facilitating. Individual interviews $(60-90$ minutes) provided a more confidential setting and enabled topics that were potentially more sensitive to be addressed, such as (non-)compliance with rules and regulations or assessments of the different actors in the NIP. The survey indicates that there is a majority of women among NIP service providers and this is reflected in our qualitative sample.

\section{Individual interviews with thirty-five NIP participants}

It is the local service providers - teachers and case workers - who are at the centre of our analysis. But to balance and broaden our understanding of how different types of service providers respond and relate to different types of service users, we included interpreter-assisted interviews with immigrants who were, or had been, NIP participants $(2010,2011){ }^{6}$ The interviews were semistructured and lasted between thirty and eighty minutes, mainly covering how the informant had experienced the different aspects of the NIP, what influence they were able to have in the drafting of their plan and what was important to 
them in their lives in Norway. The invitation to participate was mainly conveyed by NIP employees, who followed, as far as possible, our list of requirements regarding age, gender, country of origin, education, family status and work experience prior to settlement. We were conscious that this approach could make participation in our study seem obligatory and make the participants wary of criticising the programme. To make clear that their anonymity would be preserved, all information was repeated before the interview commenced and they were asked once more if they would like to participate. There is a majority of women among the informants. The data are therefore particularly valuable for illuminating challenges female participants might encounter in a work-oriented, full-time activation programme.

\section{Survey of 329 NIP caseworkers in a representative sample of Norwegian municipalities}

Invitations to participate were sent to the 256 municipalities that had accepted refugees for settlement in the three years prior to the survey. In each of the 220 municipalities that responded, up to four caseworkers were invited to answer questions concerning their everyday implementation of the programme, including several open-ended questions. The topics included factual questions about the implementation of the NIP, but also questions relating to more normative topics concerning the delimitation of service providers' and service users' responsibilities. The response rate was high -84 per cent. As most Norwegian municipalities are small and settle refugees in limited numbers, ${ }^{7}$ very few employed more than four caseworkers within the programme. Even so, we are aware that our sample of caseworkers is not entirely representative for the total population of caseworkers due to a systematic oversampling of caseworkers in smaller organisations.

\section{Carers and Clerks}

The 'Carer' and the 'Clerk' are analytical categories. Most service providers are a mix of the two that most likely will vary over time and according to the situation. But to provide the reader with some idea about the distribution of rule-orientation and care-orientation, we will analyse a few relevant dimensions included in our survey of NIP caseworkers.

The data from the web-survey allow us to divide the 329 caseworkers into categories of predominantly Carers or predominantly Clerks. The categorisation can be done in various ways. We have chosen a quite simple approach by using the answers to the statement: 'I often help participants with issues that lie outside the framework of the programme.' By defining those who answer that this statement 'fits very well' as predominantly Carers and the others as predominantly Clerks, we split the sample into two equal halves. By analysing how these categories 
respond to other statements that relate to the 'Carer' and 'Clerk' definitions, such as the inclination to interpret regulations flexibly and working more than office hours in order to serve clients, we find some coherence in the dimensions. The Carers are more inclined to interpret regulations flexibly than the Clerks ( 58 per cent versus 40 per cent) and to work more than office hours to assist their clients ( 53 per cent versus 35 per cent). ${ }^{8}$ However, there is also a considerable proportion of Clerks (by this categorisation) who interpret rules flexibly and put in extra office hours. This underscores that the caseworkers can be a mix of both types. There is also a strong association between this categorisation of 'Carers' and 'Clerks' and the caseworkers' strategies towards 'bad agency': as many as 70 per cent of the 'Carers', by this definition, state that they sometimes let users' perspectives prevail even if they disagree with these perspectives, in contrast to 49 per cent of the 'Clerks' $(p<p 0.01)$. In other words, it is quite common for caseworkers to show some leniency in cases of 'bad agency', but more so for 'Carers' than for 'Clerks'.

In the next two sections, we will return to the qualitative data to study in more detail the caseworkers' understandings of, and strategies for, user influence when faced with different categories of users - the Pawns and the Disagreeing Queens. The categorisations of service users and service providers in the following sections are qualitative and not based on the quantitative survey presented in this section.

\section{From Pawn to Queen}

Service providers in the NIP face service users from all levels of educational backgrounds (including no education at all), family structures, work experiences and health issues. Service users' ability to engage in planning activities within the programme will naturally vary. Most service providers agree that user influence involves people having a say in matters that concern them. To ask, to take time to listen and to educate are commonly mentioned both by caseworkers and teachers within the NIP when we ask them to define and elaborate on the concept of user influence.

The time and learning aspect of user influence described by service providers was also addressed by service users. One of the participants we interviewed was a mother of three from Somalia in her early thirties. At the time of our interview, she had lived in Norway for four years. The NIP only lasts for two or a maximum of three years, but she was still in the programme at the time of our visit due to two periods of maternity leave after her arrival in Norway. ${ }^{9}$ We asked her if her caseworker had enquired about her wishes and aims. She responded:

Participant 1: I wasn't sure what I could do when I first came here. Only that I wanted to work. Perhaps something with children ... or cooking. We (referring to her caseworker) talked about different jobs you can have in Norway and 'Tom' said I should talk to people I knew who had been here a while and then think with my heart. He said it that way - think with your heart. I 
did, and decided that I wanted to try to qualify to work in a nursing home. But if that doesn't work out a childcare centre is also ok. I can do many things ... I think.

Her story is similar to many of the stories we heard when we posed this question to NIP participants. A feeling of uncertainty at first, but, given some time to think as well as information about alternatives and practical experiences, participants gain a growing sense of available possibilities.

Other participants have clear goals but are less confident about how to reach them. Some express annoyance over the expectation that they should be involved in the drafting of the plan. An Afghan man, aged twenty-four, had enrolled in the NIP one and a half years prior to our interview. He wants to become a car mechanic, but offered no opinions as to what sort of training he would prefer in order to reach his goal. He said:

Participant 2: I didn't go to school in Afghanistan, so I don't know ... )] I do not know the rules in Norway, or what it is like here. I trust that they (referring to the teachers and his caseworker) know best.

The NIP has an ambition to empower programme participants, and user influence is mentioned as a way to accomplish this. But programme participants are not necessarily interested in getting involved in putting together a qualification plan, even though they may have concrete plans for the outcomes of programme participation. A similar point is made by Boehm and Staples (2002), who found that service users and service providers have different views on what empowerment entails. While service providers put emphasis on process, the most important aspect for service users was concrete outcomes: better housing, employment, income etc.

Both the care- and the rule-oriented service providers are aware of the challenges of furthering user influence when the users do not express their preferences. Still, they tend to respond differently when they face participants who either offer no opinions on programme targets or do have goals but leave it up to the caseworker to decide on how best to reach them. Two service providers, both with many years of experience, gave contrasting accounts of how they approach participants who struggle to relate to the choices they are asked to make within the programme framework:

Carer: Well, my definition of user influence is that they (the participants) always have the last word. My job is to supply information, but also to offer counsel. But it is they who must make the choices.

Clerk: You need to formulate your expectations about them getting involved in the choices they have to make about their future ... And still, you sometimes have to decide for them - their process can take too long.

Typically, both the Carer and the Clerk will allow the participant to consider different alternatives during the first months when they are busy mainly with 
language classes. Then, the Clerk tends to decide on a plan on behalf of the participant. The Carer will be inclined to postpone the decision and focus her efforts on educating the participant to form and to articulate his/her opinions. In some cases, this strategy will gradually give the 'Pawn' more of a voice and move them toward becoming a 'Queen'. This will be a high priority for the 'Carer' and in their mind make the participant more skilled to take on new challenges even if the programme is completed without (for example) work training. For the 'Clerk', complying with programme requirements will have a higher priority. They will tend to decide on behalf of the participant rather than wait. The 'Clerk' will also be inclined to argue that there is little point in waiting too long for the participant to form an opinion, and that it is the final result more than the process that is important.

\section{Disagreeing Queens}

Both caseworkers and participants tell stories about disagreement, naturally more related to Queens than Pawns. Negotiations over such disagreements are a central element of user involvement, and the aim of the service provider must be to reach an agreement on key issues such as ambitions and programme components. Often this is achieved, but negotiations do not always yield agreement. An important question then is whether such unresolved disagreements leave room for user influence at all.

A topic that often comes up concerns programme content - language classes, work training or both? One participant described how she perceived her situation as inflexible. She said:

Participant 3: Mostly, the thing we disagreed about was the work training. I learned more at school and wanted to combine work and Norwegian language classes, three days' work and two days of school, but they said no.

Interviewer: Did you try to persuade them?

Participant 3: No ... You just can't. It is not you who decides. It doesn't help to discuss or present new arguments. They say "You have to". "There's nothing more to discuss" they say ... So no, I did not try to argue or debate.

In this case, the participant's wishes were overruled and her continuing disapproval might have gone undetected by her caseworker as she no longer saw any point in arguing her case. On the other hand, we also find examples of participants who feel that their opinions have been taken seriously and that service providers sometimes change their minds. A Somali woman approaching the end of her programme responded to our inquiries about her influence on the programme content this way:

Participant 4: You just need to say what you want and what you don't want. He (referring to her caseworker) hasn't sent me on work training and if you don't want to do work training you just tell them that. You can say no. 
In her case, it is fair to say that she still had a long way to go before regular employment was a realistic option. She was in poor health and had no prior school or work experience. Her caseworker might have felt there would be little to gain by forcing her to participate in work-related activities. Nevertheless, how service providers handle participants with a clear, voiced agency varies. In this particular case, participant 4 voiced her opinion and, as far as our data show, her caseworker gave in, in respect that he did not comply with the programme's demand of including work training within the programme period.

In our survey of NIP caseworkers, close to 60 per cent confirmed that they sometimes let the participant's view affect programme decisions, even if they disagreed with the participant's view. But why do service providers sometimes give in to the wishes or demands of service users even if they believe that, by doing so, the programme becomes less effective? According to our model, the Clerks will rely mostly on the overall target of employment and what NIP regulations state about the role of work training to guide their decisions. They are less likely to be found in the group of caseworkers who sometimes give in to the wishes of participants contrary to their better judgements. The Clerk will overrule the judgements of a Disagreeing Queen. In contrast, Carers tend to regard the participant's own motivation and plans as essential for success, even if it entails fewer programme hours and no work training at all. Reflections from two experienced service providers, can serve as examples of each type of bureaucratic response:

Carer: Sometimes I give in to wishes that will give them a less effective programme. But still, when you manage to argue and quarrel yourself out of work training and into a third year of language classes because you feel safer that way, you have to agree that that is user influence and a good thing.

Clerk: Many participants have overly ambitious plans that cannot be met within the programme. They need to be informed of the realities ... sometimes we have to take people out of the programme. But for the most part, I tell them how it has to be. Then we might fall out for a while, but it usually sorts itself out in the end.

We also find cases where a transition from 'bad agency' to 'good agency' is achieved through a redefinition by the service provider of what 'good agency' is, often related to the overall goal of the activation programme. This is an adaptation typically made by Carers and involves not only bending, but even breaking, the regulations of the NIP. The examples we have encountered all relate to the situation for mothers. The NIP participants often emphasise that to take care of children after settling in a country that is very different from where you grew up, and often without support from family and friends, is time-consuming. This constitutes a dilemma for service providers who see the mothers' challenges in their everyday life, but at the same time are responsible for the implementation 
of a full-time programme with employment and economic self-sufficiency as its main goal.

Carer: I think that we ask too much too fast from some of these women. They have so many responsibilities at home and are so tired ... If she can be a good mother and take care of her children, I think that is a good result.

Clerk: I think there is a lot of tradition here - that they (women) should stay home, cook, and care for children. It is important not to 'understand' too much. Combining employment and children is a struggle for all of us ... They need to learn to hurry.

Clerks can also struggle with ambivalence when confronted with participants who have time-consuming care responsibilities. But, compared to the Carers, they are less inclined to condone a less intensive (not full-time) and less employmentrelated (no work training) plan for mothers. Their argument is usually that the strict activation line is for the best in the long run, both economically and with regard to gender equality. Carers, on the other hand, often question the overall target of paid employment for women with little education, no prior work experience and large care responsibilities, and resent what they perceive as the central government's single focus on employment. In these cases, some of the service providers adjust the programme's intensity and concentrate on programme targets other than paid employment. This is a strategy that, from the outside, resembles 'giving in' to a Disagreeing Queen - with the exception that the service provider does not really disagree. That is, they disagree, but with the policy they are meant to enforce, not with the service user they are meant to enforce it upon.

\section{Discussion, conclusion and suggestions for further research}

In this article, we have examined how user influence is shaped by the characteristics of service providers and service users respectively. Inspired by Le Grand (2003/06), but also by the critique of his model, we have framed the empirical analysis by categorising service providers according to their practices, as either care-oriented (Carers) or rule-oriented (Clerks), and service users according to their agency, as either autonomous (Queens) or passive (Pawns). Both Carers and Clerks find user involvement to be challenging, particularly when users are Pawn-like or display 'bad agency'. Carers and Clerks respond to these challenges differently, with corresponding consequences for the implementation of user influence. When met with Pawn-like users, the Clerk is inclined to decide goals and measures on behalf of the user. When faced with 'bad agency', in other words service users that have preferences that are incompatible with the goals or the methods of the programme, these preferences tend to be overruled. Clerks listen to the users' opinions, but do not engage in negotiations over what they perceive to be the overall aim of the programme. The Clerk emphasises being on 


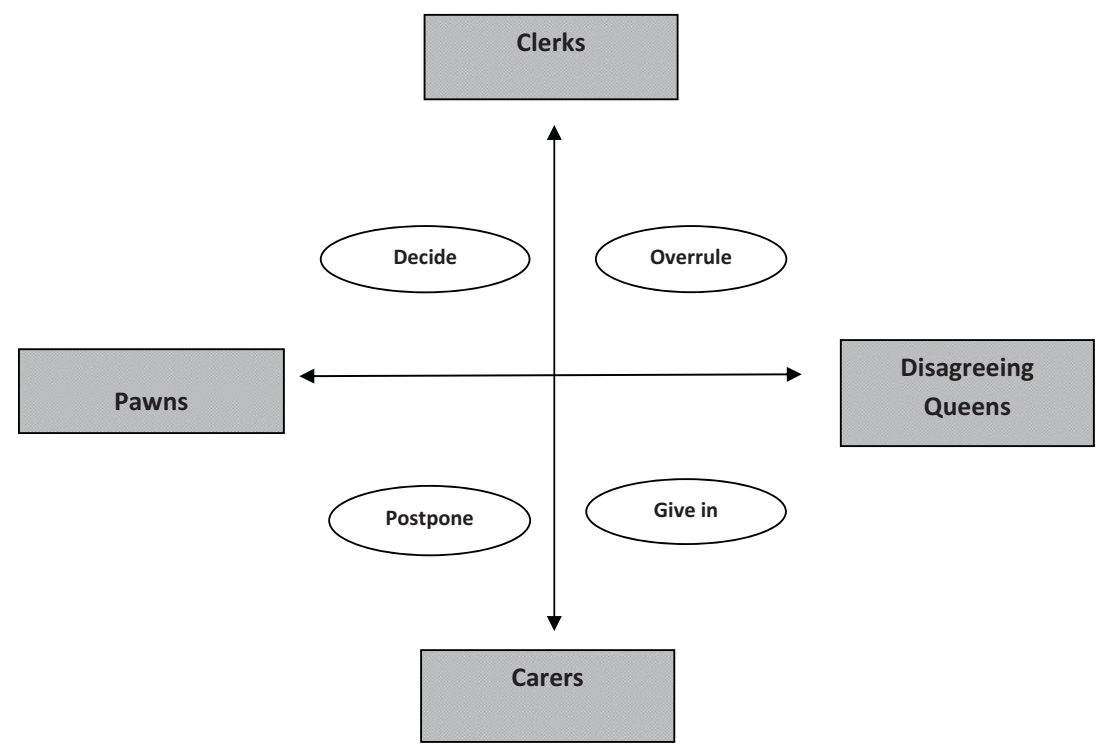

Figure 2. Interaction outputs, by axes of service-provider approach and service-user agency

friendly terms with the users but maintains a professional distance in relation to topics and tasks that she perceives to belong to the private sphere - their own, as well as the user's.

The Carer on the other hand typically shows pronounced reluctance to overrule the choices made by the service user. This is rooted in a substantially different understanding of user influence compared to that of the Clerk. The Carer sees the process of involvement as empowering, educational and necessary in order to reach long-term goals of economic and social inclusion in society. In this respect, the Carer relates closely to what Dean (2003b) has described as activation of the human capital type. In order to achieve user involvement, the Carer is prepared to wait - sometimes for a very long time - before they draft a plan or demand that the user participates in programme activities that he or she is not motivated to do. In this and other respects, the Carer is also inclined to stretch the rules to comply with the wishes of the service user, based on her general belief that user influence is highly educational for the participants, and essential for their inclusion in society.

To balance user influence with policy ambitions of rapid economic and social integration of immigrants can be a challenging task for service providers. Both Pawns and Disagreeing Queens can put the service providers to the test, although in different ways. We have illustrated the different strategies service providers apply to cope with these challenges in Figure 2.

When Carers are confronted with Pawns, they tend to postpone decisions and wait until the service user expresses stronger agency. When met with Disagreeing 
Queens, they are inclined to give in to the wishes of the service user, even though they might not think the goals and measures the service user suggests are the best ones. The Clerks on the other hand, tend to decide on behalf of the Pawns, and to overrule wishes from Disagreeing Queens. Strictly speaking, only one of these strategies actually entails user influence: when Carers give in to Disagreeing Queens. If the service provider has a good reason for disagreeing, this is not a very good outcome. All four outcomes are rather examples of failed implementation of user influence - so far. They may, however, be part of a long-term ambition to turn Pawns into Queens, and 'bad agency' into 'good agency'.

The findings also invite a somewhat broader discussion of the ambivalence service providers experience in trying to balance the programme's goal of employment with how the participants perceive their present and envisage their future. Hagelund (2005) has described how street-level bureaucrats sometimes struggle with their impulses to 'be kind' to service users, because this in the long run can turn out to be 'bad' in terms of integration. She interprets this within a broader discourse of integration crises that emerged in Norway in the late 1990s, where 'kindness' was seen as source of 'clientification'. The NIP was introduced in part as an answer to the critique and close to 90 per cent of the local service providers believe that the NIP has improved the introduction of newcomers into Norwegian society (Kavli et al., 2007). Even so, implementing activation policy measures of economic sanctions towards participants who are already economically marginalised, provide for children and/or do not share Norwegian gender equality values, clashes with the values and professional ethics of many caseworkers. In particular, the Carers are inclined to give in to 'Disagreeing Queens' when caring responsibilities and motherhood are brought to the table. In this way, the service providers' understanding of 'good agency' is flexible - sometimes far beyond the regulations of the programme. Women can receive plans that are endorsed by their caseworkers without fulfilling the legal programme requirements. These 'rule-bendings' may also come about as a result of the service provider's assumptions about what a female Pawn 'probably' prefers.

It should be remembered that user influence is not the main ambition of the NIP. Efforts to achieve user influence must be balanced against the overall goal of transition to employment or education. When faced with Pawn-like users or Disagreeing Queens, it is not self-evident which of the service providers' practices illustrated in Figure 2 will result in optimal introductory programmes. The problem with postponing is that it may take (too) long to put together a good plan. Deciding on behalf of the participant is obviously not complying with the ambitions of user influence, but may generate a more rapid programme progression. From an empowerment perspective, it may be as important to draft efficient plans that lead to employment and good language skills as to involve the participants in decisions about the composition of the plan. Small (2000) claims 
that focusing on choices may in fact disempower service users, because many lack sufficient knowledge about alternatives and consequences.

Choosing when to overrule and when to give in is an essential part of caseworker discretion. This choice must be made in each separate case, balancing the need for good quality with the potential empowering effects of real user influence. Then again, the time and resources necessary to provide a good quality programme are not always available to the caseworkers (Brodkin, 1997; Lipsky, 1980) who are sometimes left to implement a programme that they, in the words of one of our service provider informants, 'are not very proud of. This might reduce the motivation to overrule Disagreeing Queens, and produce leniency with regard to what should be defined as 'Good' or 'Bad' agency.

Turning Pawns into Queens seems to be a prerequisite for user influence. So far, little is known about the consequences of different approaches among service providers for this process. Similarly, there is still little knowledge about the actual empowering consequences of different modes of interaction between service providers and service users. We consider these to be important issues for further research.

\section{Notes}

1 User involvement is here defined as any communication of individual characteristics, needs or preferences relevant to the shaping of the relevant service, from the user to the service provider. User influence implies that user preferences have had an actual influence on the shaping of the service.

2 Immigrants are defined as persons born abroad of two foreign-born parents and four foreignborn grandparents (Statistics Norway 2014).

3 The target group comprises people between eighteen and fifty-five years of age who need basic qualifications and who have been granted asylum or residence on humanitarian grounds, are resettlement refugees or family immigrants with the groups mentioned above. Persons who, after the breakup of a relationship, have been granted a residence permit on an independent basis due to abuse in the relationship, have been included since 1 July 2011 (Ministry of Children, Equality and Social Inclusion 2003).

4 Numbers according to the Norwegian Directorate of Integration and Diversity 2013.

5 Kavli et al. (2007), Djuve et al. (2011).

6 Three informants were recruited through Norwegian language classes (Sandbæk, 2011) and one through a network-recruitment of single immigrant mothers (Kavli, Nilsen and Sandbæk, 2010).

7 In the three years prior to the study in question, 288 municipalities received refugees for settlement. During these three years, 27 per cent of the municipalities received ten refugees or less, 24 per cent received eleven to twenty refugees, 25 per cent received twenty-six to fifty refugees and 25 per cent received fifty-one refugees or more (numbers supplied by the Norwegian directorate of Integration and Diversity, published in Kavli et al., 2007).

$8 \mathrm{p}<0.01$ for the difference between Carers and Clerks.

9 Participants in the NIP are entitled to ten months maternity leave. During maternity leave, the introductory benefit is stopped, but participants on leave can apply for social assistance. 


\section{References}

Arnstein, S. R. (1969), 'A ladder of citizen participation',Journal of the American Institute of Planners, 35: 4, 216-224.

Bloom, H., Hill, C. and Riccio, J. (2003), 'Linking program implementation and effectiveness: lessons from a pooled sample of welfare-to-work experiments', Journal of Policy Analysis and Management, 22: 4, 551-575.

Boehm, A. and Staples, L. H. (2002), 'The functions of the social worker in empowering: the voices of consumers and professionals', Social Work, 47: 449-460.

Brochmann, G. and Djuve, A. B. (2013), 'Multiculturalism or assimilation? The Norwegian welfare state approach', in Peter Kivisto and Östen Wahlbeck (eds.), Debating Multiculturalism in the Nordic Welfare States, Basingstoke: Palgrave Macmillan.

Brodkin, E. Z. (1997), 'Inside the welfare contract: discretion and accountability in state welfare administration', Social Service Review, 71: 1, 1-33.

Dean, H. (2003a), 'The third way and social welfare: the myth of post-emotionalism', Social Policy and Administration, 7: 695-708.

Dean, H. (2003b), 'Re-conceptualising welfare-to-work for people with multiple problems and needs', Journal of Social Policy, 32: 3, 441-459.

Dean, H. (2007), 'The ethics of welfare-to-work', Policy and Politics, 35: 4, 573-590.

Djuve, A. B. (2010), 'Empowerment or intrusion? The input and output legitimacy of introductory programmes for recent immigrants', Journal of International Migration and Integration, 11: 4, 403-422.

Djuve, A. B. (2011), 'Introductory programmes for immigrants: liberalism revisited, or changing ideas of citizenship?', Nordic Journal of Migration Research, 1: 3, 113-125.

Djuve, A. B. and Kavli, H. C. (2006), 'Velferdsstatens skreddere: Skjønn og brukermedvirkning i flyktningetjenesten', Tidsskrift for velferdsforskning 2006/4.

Djuve, A. B., Kavli, H. C. and Hagelund, A. (2011), Kvinner i kvalifisering: Introduksjonsprogram for nyankomne flyktninger med liten utdanning og store omsorgsoppgaver, Fafo-rapport 2011: 02.

Duncan, S. and Edwards, R. (1999), Lone Parents, Paid Work and Gendered Moral Rationalities, Basingstoke: Palgrave Macmillan.

Eriksen, E. O. (2001), Demokratiets sorte hull: Om spenningen mellom fag og politikk, Oslo: Abstrakt forlag.

Hasenfeld, Y. (1999), 'Social services and welfare-to-work: prospects for the social work profession',Administration in Social Work, 23: 3, 185-199.

Hagelund, A. (2005), 'Why it is bad to be kind: educating refugees to a life in the welfare states a case study from Norway', Social Policy and Administration, 39: 6, 669-683.

Jensen, P. H. and Pfau-Effinger, B. (2005), 'Active citizenship: the new face of welfare', in A. Andersen, M. Guilllemard, P. H. Jensen and B. Pfau-Effinger (eds.), The Changing Face of Welfare, Bristol: The Policy Press.

Jewell, C. (2007), Agents of the Welfare State: How Caseworkers Respond to Need in the United States, Germany and Sweden, New York: Palgrave Macmillan.

Jordan, B., Stråth, B. and Triandafyllidou, A. (2003), 'Comparing cultures of discretion', Journal of Ethnic and Migration Studies, 29: 2, 373-395.

Kavli, H. C., Nielsen, R. A. and Sandbæk, M. L. (2010), 'HYPERLINK "http://www.fafo.no/ pub/rapp/20176/index.html” Stønadsordningen for enslige forsørgere', Hvordan fungerer den for mottakere med innvandringsbakgrunn? Fafo-report 2010: 32.

Kavli, H. C., Hagelund, A. and Bråthen, M. (2007), Med rett til å loere og plikt til å delta: En evaluering av introduksjonsordningen for nyankomne flyktninger og innvandrere, Faforapport 2007: 34

Le Grand, J. (2003/2006), Motivation, Agency and Public Policy: Of Knights and Knaves, Pawns and Queens, Oxford: Oxford University Press.

Lipsky, M. (1980), Street-Level Bureaucracy: Dilemmas of the Individual in Public Services, New York: Russell Sage Foundation. 
Loyens, K. and Maesschalck, J. (2010), 'Toward a theoretical framework for ethical decision making of street-level bureaucracy: existing models reconsidered', Administration and Society, 42: I, 66-100.

Marston, G., Larsen, J. and McDonald, C. (2005), 'The active subjects of welfare reform: a street-level comparison of employment services in Australia and Denmark', Social Work and Society, 3: 2, 141-158.

May, P. and Winter, S. (2007), 'Politicians, managers, and street-level bureaucrats: influences on policy implementation', Journal of Public Administration Research and Theory, 19: 3, 453-476.

Minas, R. (2009), Activation in Integrated Services? Bridging Social and Employment Services in European Countries, Working paper 2009:11, Stockholm: Institute for Future Studies.

Ministry of Children, Equality and Social Inclusion (2003), The Introduction Act 2003 (LOV-2003-07-04-80), The Act on an Introduction Programme and Norwegian Language Training for Newly Arrived Immigrants, http://www.ub.uio.no/ujur/ ulovdata/lov-20030704-080-eng.pdf.

Official Norwegian Report 2011: 7 (NOU), Welfare and Migration: The Future of the Nordic Model, Report submitted to the Ministry of Children, Equality and Social Inclusion, http://www.regjeringen.no/pages/16413697/nou_2011_7_perspective_andsummary.pdf

Olsen, B. (2014), 'Flyktninger og arbeidsmarkedet, 4 kvartal 2012', Rapporter 2014/6, Oslo: Statistics Norway.

Proposition to the Odelsting nr.28 (2002-2003), Om lov om introduksjonsordning for nyankomne innvandrere (introduksjonsloven), http://www.regjeringen.no/en/dep/ asd/doc/regpubl/otprp/20022003/otprp-nr-28-2002-2003-.html?id=171771.

Sandbæk, M. L. (2011), 'Voksne innvandrere i Norskopplæringen: Brukerundersøkelser i Basis og Helsefagarbeideropplæringen', Fafo-notat 2011:03, Oslo: Fafo.

Sainsbury, R. (2008), 'Administrative justice, discretion and the "welfare to work" project', Journal of Social Welfare and Family Law, 30: 4, 323-328.

Small, N. (2000), 'The changing National Health Service: user involvement and palliative care', in N. Small and P. Rhodes (eds.), Too Ill to Talk: User Involvement in Palliative Care, London: Routledge.

Statistics Norway (2014), Innvandrere og norskfødte med innvandrerforeldre, 1 January 2014, Publisert: 24 April 2014.

Taylor-Gooby, P. (2005), 'Ideas and policy change', in P. Taylor-Gooby (ed.), Ideas and Welfare State Reform in Europe, Basingstoke: Palgrave Macmillan.

Terum, L. I. (2003), Portvakt i velferdsstaten: Om skjønn og beslutninger i sosialt arbeid, Oslo: Kommuneforlaget.

Van Berkel, R. (2007), 'Individualized activation in the EU', in R. Van Berkel and B. Valkenburg (eds.), Making It Personal, Bristol: The Policy Press.

Van Berkel, R. and Van der Aa, P. (2012), 'Activation work: policy programme administration or professional service provision?', Journal of Social Policy, 41: 4, 493-510.

Van Meter, D. and Van Horn, C. E. (1975), 'The policy implementation process: a conceptual framework', Administration and Society, 6: 4, 445-488.

Weber, M. (1920/1978), Economy and Society, Berkeley, CA: University of California Press.

Wright, S. (2012), 'Welfare-to-work, agency and personal responsibility', Journal of Social Policy, 41: 2, 309-328. 